Rapp. Grønlands geol. Unders. 112, 113-127 (1983)

\title{
A description and interpretation of the Proterozoic Kobbefjord Fault Zone, Godthåb district, West Greenland
}

\author{
George M. Smith and Robert F. Dymek
}

\begin{abstract}
The Kobbefjord Fault Zone (KFZ) is recognized as the largest of a group of early Proterozoic dextral transcurrent fault zones that cut Archaean gneisses in the vicinity of Godthăb. Detailed field study of the KFZ reveals that it corresponds to a zone of deformation and alteration $\sim 100 \mathrm{~m}$ wide, which completely obliterate pre-existing structures in country rock gneisses. Rocks within the KFZ are dominantly quartz-rich laminated mylonites characterized by regionally consistent NE-SW trending subvertical foliations and subhorizontal lineations. Such mylonites were produced by intense ductile deformation, although local pseudotachylites and cataclasites occur which indicate minor amounts of brittle deformation as well. Alteration in the KFZ involved pervasive pink staining and/or bleaching, and development of hydrated mineral assemblages (Chl $+\mathrm{Ep}$ + Musc), indicating an important role for fluid flux during the faulting process. Movement on the KFZ was probably initiated in the time period 2000-1800 Ma, as it displaces mafic dikes which appear correlative to dikes to the north of the Godthåb area which yield ages in this range. Deformation in the KFZ most plausibly represents internal deformation of a stable continental block subjected to compression on at least two sides. Data for fabric elements in the KFZ and for associated conjugate shears indicate that the principal compressive stress $\left(\sigma_{1}\right)$ for this faulting episode was oriented $\mathrm{W}-\mathrm{NW}$, but precise relationships to deformation events on the margin of this block have yet to be deduced.
\end{abstract}

\section{Introduction}

In this paper, we describe and interpret the principal characteristics of relatively shallow level post-Archaean intracratonic fault zones in the region of Godthåbsfjord, West Greenland, based primarily on a detailed study of the Kobbefjord Fault Zone (KFZ), the largest and most continuous fault zone recognized in the area. We summarize our observations on the physical aspects of the KFZ, the types of deformation and alteration associated with it, and the nature of rocks formed in the fault as a result of these processes. We then compare our results to previous studies of faulting in regions to the north and south of Godthåbsfiord, and discuss these observations in the context of the timing of deformational events on the margins of the Archaean craton during the time period $\sim 2000-1500 \mathrm{Ma}$. The implications of the patterns of faulting for the regional stress field orientation are also considered. 


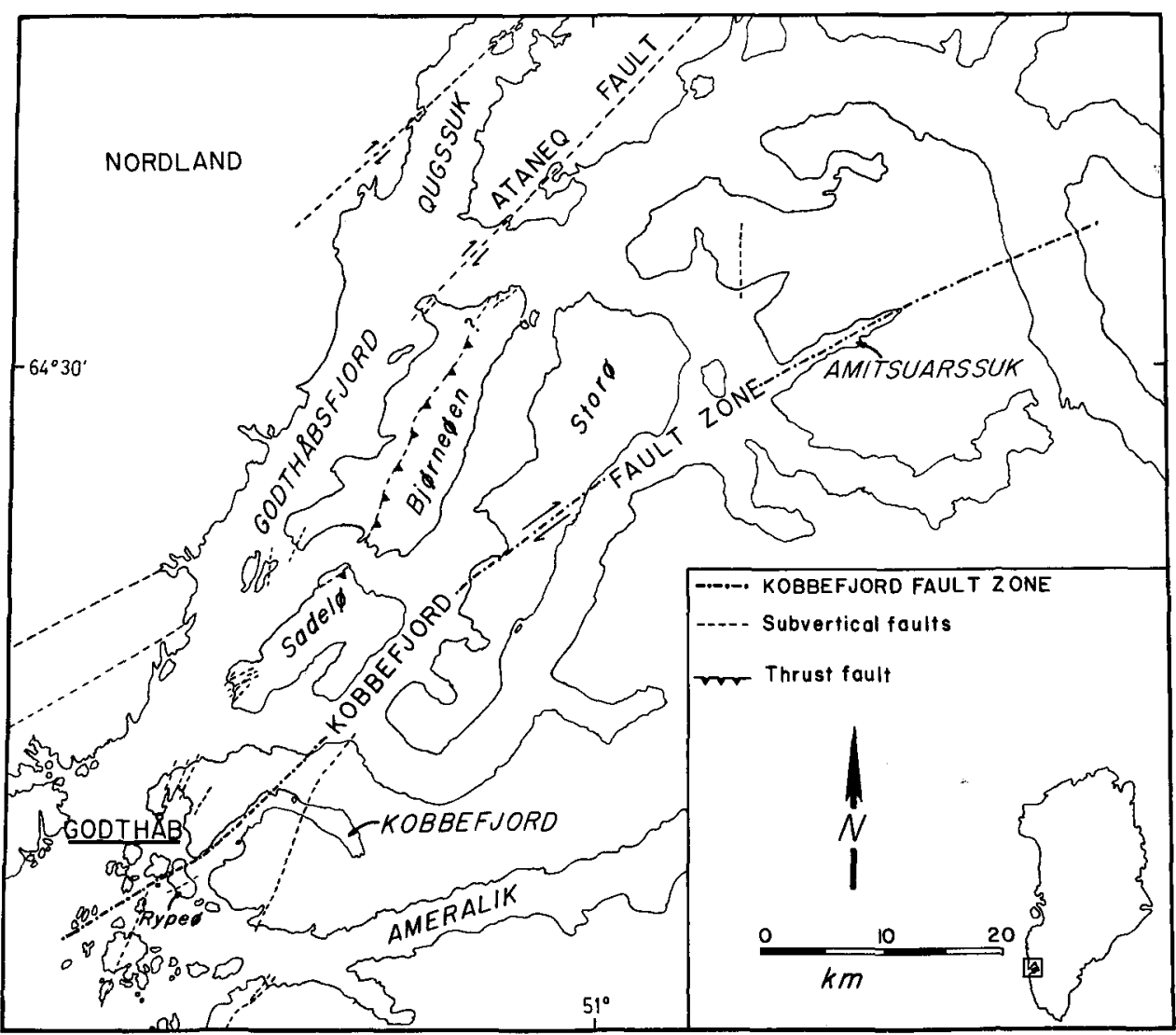

Fig. 1. Location of the Kobbefjord fault zone and other faults of probable similar age in the region of Godthåbsfjord.

\section{The Kobbefjord Fault Zone}

\section{Megascopic characteristics}

The KFZ trends $040-060^{\circ}$ over a distance of $>80 \mathrm{~km}, \sim 35$ of which is exposed on land (fig. 1). The fault traverses a quartzofeldspathic gneiss terrain along its entire length, and locally cuts anorthosite, Malene supracrustal rocks, and Qôrqut granite. Displacement of a paragneiss sequence on the southern end of Store Malene suggests dextral transcurrent movement of $\sim 5 \mathrm{~km}$. The fault zone typically forms a pronounced, eroded topographic depression up to $\sim 100 \mathrm{~m}$ wide, which corresponds to a zone of deformation also up to $100 \mathrm{~m}$ wide, and a zone of alteration that is locally twice as wide. The KFZ is subvertical along its entire length, but there are slight variations in the orientations of fault-related foliations and lineations from locality to locality.

Ductile deformation dominated the faulting process, which resulted in the progressive development of fine-grained laminated mylonites. Brittle deformation also operated locally, as indicated by the presence of cataclasites and pseudotachylites. Alteration associated with 

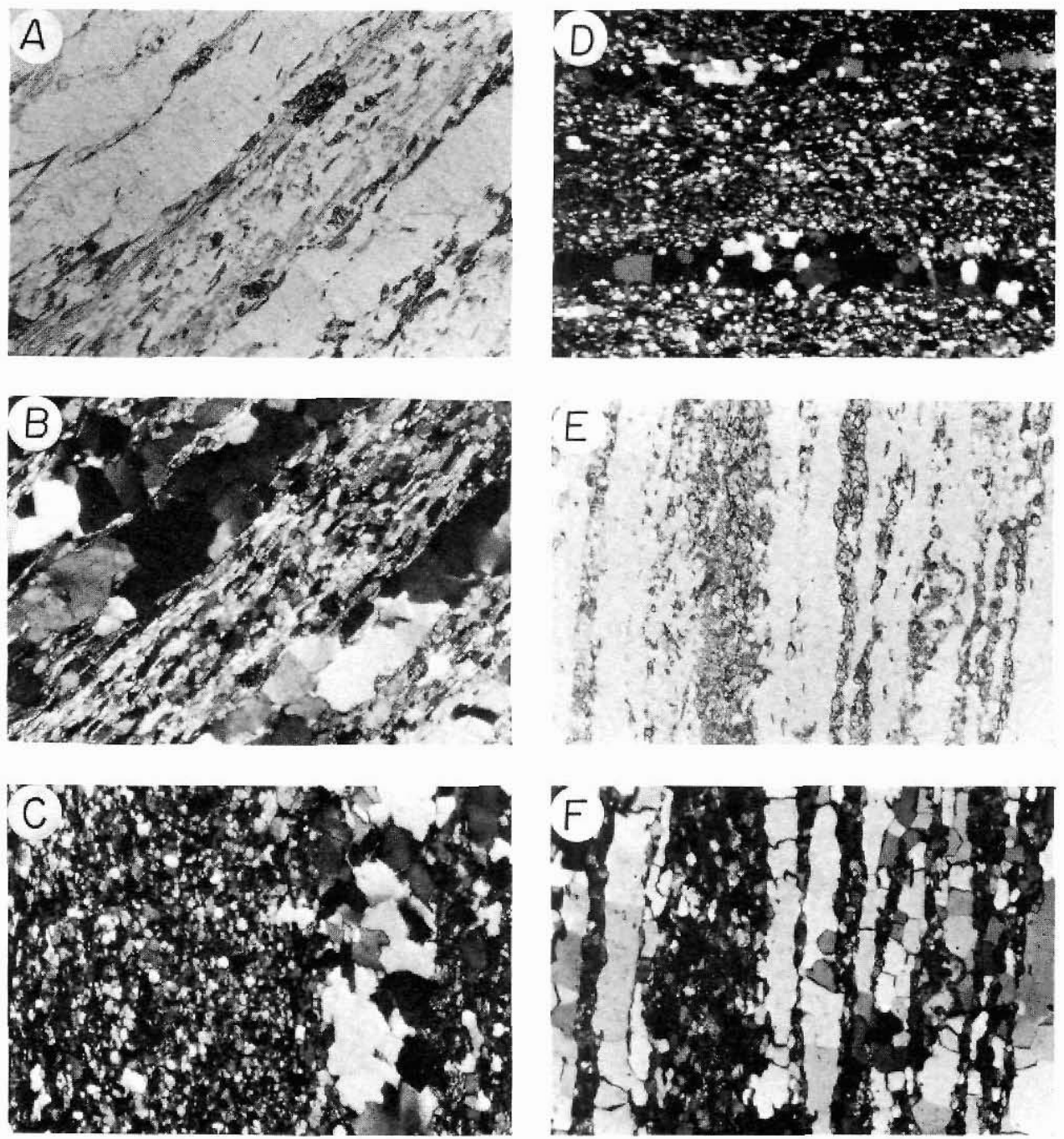

Fig. 2a, b. Laminated mylonite viewed in plane- and cross-polarized light showing coarser-grained quartz-rich layers and fine-grained layers with clouded feldspar, elongated biotite, muscovite and chlorite, and granular epidote. (GRD-2014, KFZ-Kobbefjord). c, d. Laminated mylonites illustrating variation in texture and grain size of coarser-grained layers and relative constancy for grain size in finerlayers (C: GRD-1961, KFZ-Kobbefjord; D: GRD-2006, KFZ-Kobbefjord). e, f. Recrystallized mylonite from zone of intense alteration viewed in plane- and cross-polarized light; blocky dark mineral is epidote; clouded material is feldspar (GRD-223, KFZ-Storø). (Horizontal dimension is $2.2 \mathrm{~mm}$ in all photographs).

the fault is developed sporadically, and can be recognized by a characteristic salmon-pink to green staining and/or bleaching. Such alteration represents retrograde hydration, carbonation and oxidation which occurred penecontemporaneously with faulting. 


\section{Fabric elements}

A pronounced planar/linear fabric is developed in the KFZ which is characterized by (1) a regionally consistent foliation that completely obliterates pre-existing rock fabric, and (2) a marked reduction in grain size compared to surrounding gneiss. The resultant fault rocks are thus true mylonites in the sense of Bell \& Etheridge (1973) and Sibson (1977), in that quartz grains have undergone intense intracrystalline plastic deformation, dynamic recovery and recrystallization to a finer grain size.

The planar fabric is comprised primarily of narrow bands $(<1 \mathrm{~mm})$ of elongated and 'flattened' quartz grains or ribbons separated by wider bands $(1-5 \mathrm{~mm})$ of fine-grained, recrystallized quartz, clouded feldspar, granular epidote, biotite and muscovite oriented parallel to the foliation (cf. fig. 2).

The foliations range from planar to undulating where a significant number of augen are present or the degree of deformation is low. In general, the degree of planarity of the mylonitic foliation increases with increasing extent of deformation, and the width of individual laminae that mark the foliation decreases (to $<1 \mathrm{~mm}$ ) in the most deformed rocks.

The lineation in the KFZ is comprised of elongated feldspar augen and/or quartzofeldspathic aggregates, elongated quartz grains or ribbons, and more rarely, tabular grains of biotite or white mica. The long axes of any of these elements invariably lie in the plane of the mylonitic foliation.

Summaries of our observations on these fabric elements at four localities are outlined below.

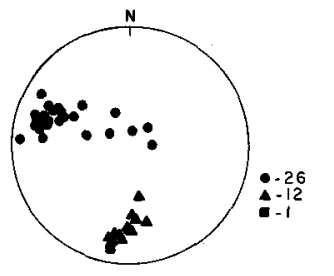

Nûk Gneiss

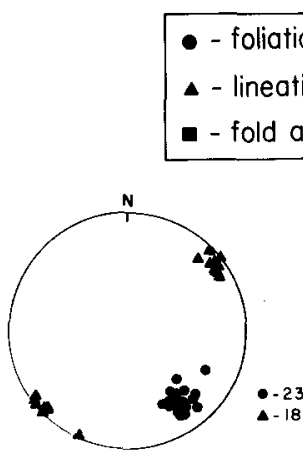

Fault Zone - West Coast
PYPE $\varnothing-K F Z$

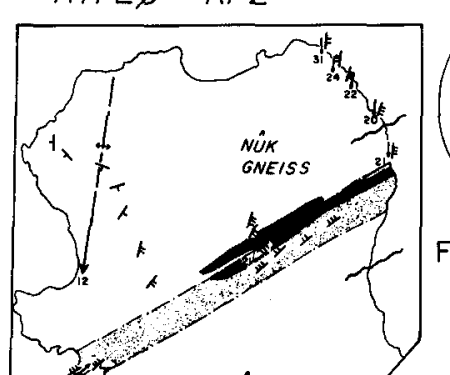

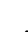

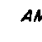

AMiTSOO GNEISS
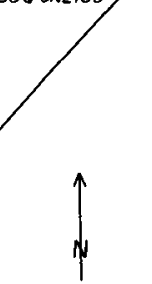

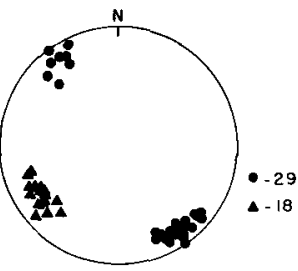

Fault Zone - East Coast

MAP LEGEND

Alteration Zone $\approx$

m 0.30

Foliation $\begin{array}{r}30-60 \\ m \text { 60-90 }\end{array}$

Lineation $\rightarrow 25$

Kobbefjord $-1-\bar{E}$

Foult Zone --

Mafic Dike

$0.0 \quad \mathrm{~km} \quad 0.5$

Fig. 3. Geology and structural data for the Kobbefjord fault zone on Rypeo. All plots in this and the following figures are lower hemisphere equal area projections. 


\section{Rypeø}

The generalized geology of the northern part of this island is illustrated in figure 3 . The KFZ on Rypeø is $\sim 100 \mathrm{~m}$ wide, and separates Nûk gneiss on the north from Amîtsoq gneiss on the south. Rocks in the fault zone are intensely altered, and this zone of alteration extends well into the gneisses on the north and south sides of the fault. A thick, sheared mafic dike parallels the fault zone at its northern margin.

The insets on figure 3 illustrate measurements of mylonitic foliations and lineations in the KFZ, together with measurements on gneissic foliations and lineations in Nûk orthogneiss from north of the fault zone. On the west coast of Rypeø, the lineations in the KFZ are subhorizontal with average trend $\sim 055^{\circ}$; here, mylonitic foliations strike $055^{\circ}$ and dip $75^{\circ} \mathrm{NW}$. Approximately $1 \mathrm{~km}$ to the northeast, on the east coast of Rypeø, the lineations trend $235^{\circ}$ and plunge only to the $\mathrm{SW}$, whereas foliations are subvertical. From coast to coast on Rypeø the fault zone strikes $\sim 055^{\circ}$, and the foliations are oriented parallel to this. Note that the fabric elements in Nûk gneiss are distinctly different from those in the KFZ.

\section{Kobbefjord}

The geology of the KFZ in the vicinity of Kobbefjord is illustrated in figure 4 . The fault zone here ranges from 100-150 m wide, and traverses a terrain dominated by Nûk gneiss. Alteration in the KFZ is intense and disposed asymmetricaly with respect to the zone of

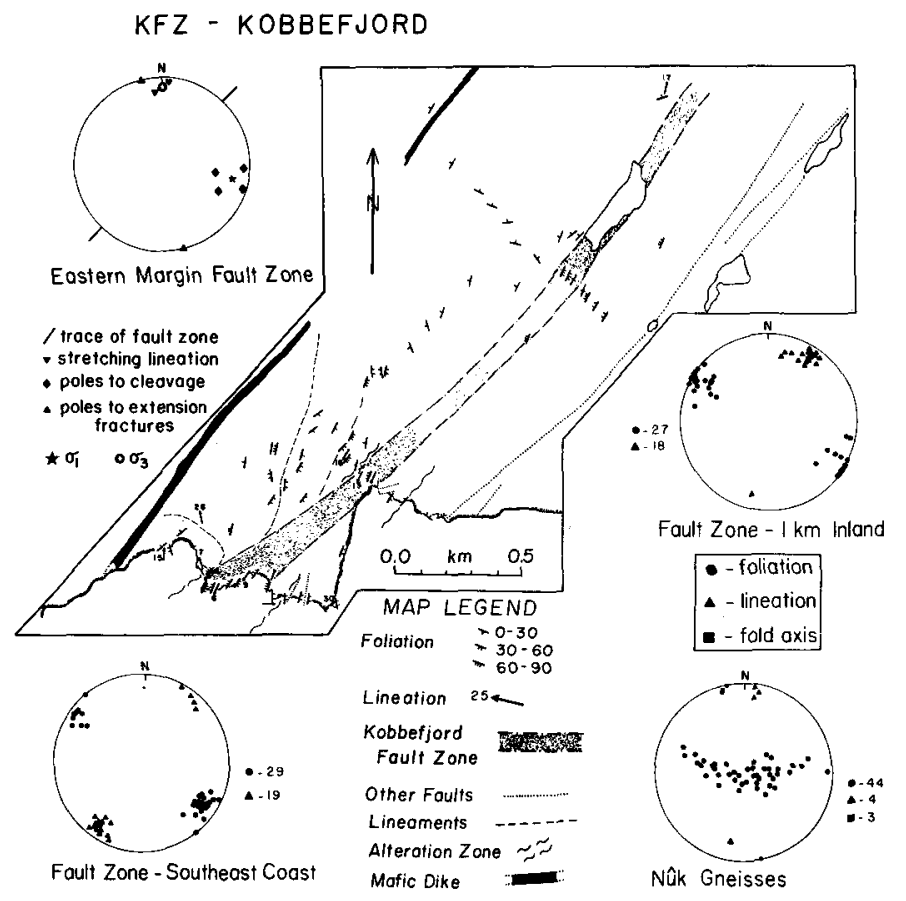

Fig. 4. Geology and structural data for the Kobbefjord fault zone in Kobbefjord. 


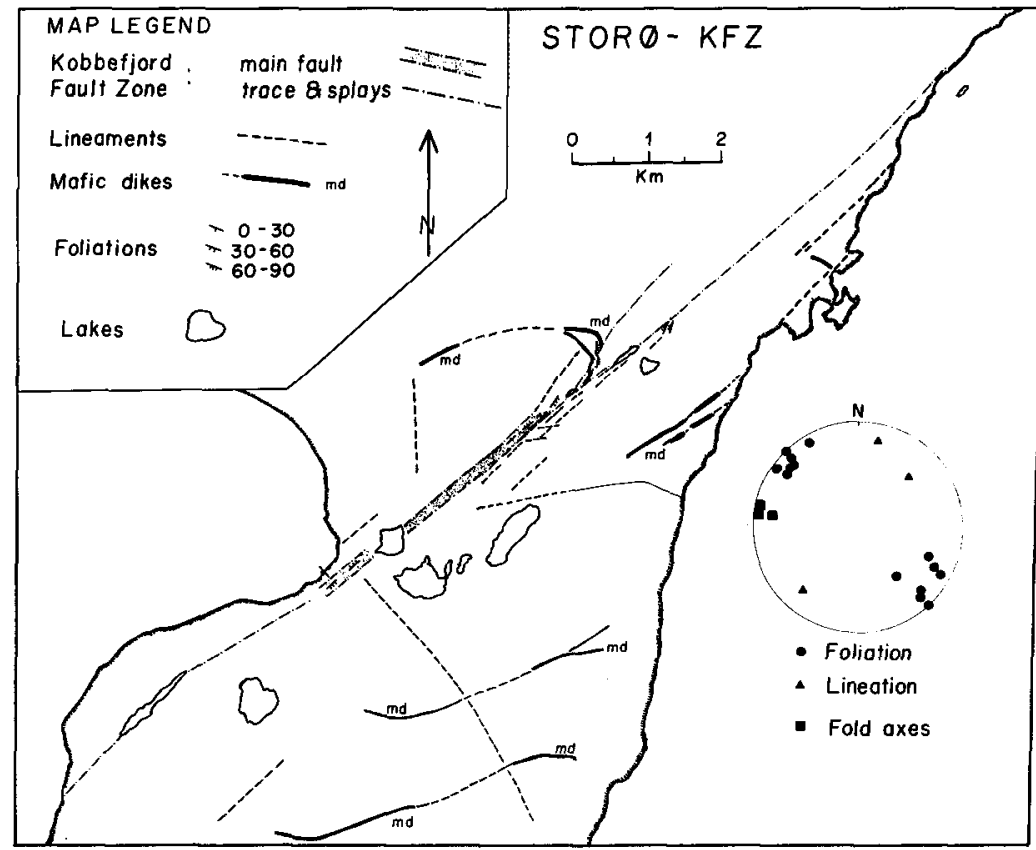

Fig. 5. Geology and structural data for the Kobbefjord fault zone on Storø.

greatest deformation. A series of subparallel faults occur to the south-east of the main fault zone, which may indicate that deformation here was dissipated over a much wider zone than indicated by the present position of the main fault zone. Several prominent lineaments emanate from the north side of the main fault; these appear to represent conjugate shears that formed during faulting. A thick mafic dike parallels the KFZ a few hundred meters to the north-west, which is most likely the same dike that occurs within the fault zone on Rypeø.

As shown by the insets on figure 4, most lineations measured at the south-east coastal exposure trend $\sim 215^{\circ}$ and plunge gently to the $\mathrm{SW}$, whereas foliations strike $\sim 035^{\circ}$ and have subvertical dips. Approximately $1 \mathrm{~km}$ inland, lineations trend $\sim 030^{\circ}$ and plunge to the $\mathrm{NE}$, and foliations strike $\sim 035^{\circ}$ and are subvertical. The fault zone here strikes $\sim 045^{\circ}$, and has a clockwise sense of rotation with respect to the mylonitic foliations, which is consistent with dextral transcurrent movement. The insets in figure 4 also demonstrate that the orientations of fabric elements in the fault are distinctly different from those in country rock gneiss.

\section{Storø}

The geology of the KFZ on Storø is illustrated in figure 5. The south-west segment of the fault zone is $\sim 100 \mathrm{~m}$ wide, and similar to the occurrences described above. Several subparallel lineaments, which contain fault rock, are found within a few hundred meters of the main fault zone at this locality. Mafic dikes are common here, one of which has been rotated 
Fig. 6. Structural data from small shears near the Kobbefjord fault zone in Amitsuarssuk.

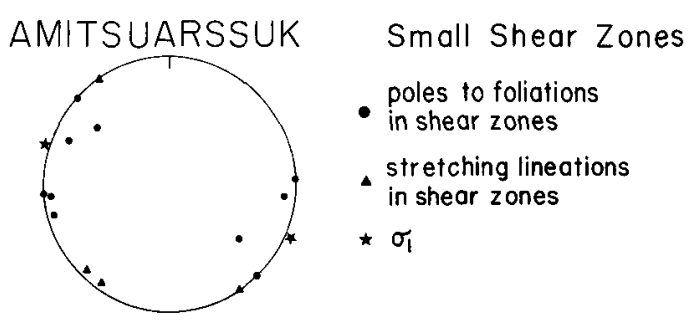

into the fault zone during deformation; the sense of rotation of this dike is consistent with dextral transcurrent movement. Poor exposure precludes a thorough characterization of the northeast segment of the fault zone, and it is indicated on figure 5 by a single fault trace.

Mylonitic foliations strike $\sim 045^{\circ}$ with variable sub-vertical dips, and the few available measurements on lineations show the general NE-SW trend found on Rypeø and in Kobbefjord. The main fault zone here strikes $\sim 055^{\circ}$ and, as in Kobbefjord, is rotated clockwise relative to the mylonitic foliation trend, consistent with dextral transcurrent movement.

\section{Amitsuarssuk}

Six small shear zones $\sim 1 \mathrm{~m}$ wide with a range of orientations were identified along the southeast coast of this fjord. These are characterized by subvertical mylonitic foliations and subhorizontal stretching lineations (figure 6), not unlike those in the KFZ proper.

The $\sim \mathrm{N}-\mathrm{S}$ and N-NE trending shears may represent a conjugate set. As summarized by Ramsay (1980), the greatest principal compressive stress $\left(\sigma_{1}\right)$ bisects the obtuse angle between conjugate non-brittle shears. The conjugate shears in Amitsuarssuk yield a W to NW trend for $\sigma_{1}$, which is consistent with dextral transcurrent movement.

\section{Deformation}

\section{Ductile deformation}

The nature of ductile deformation processes and features indicative of subsequent recovery and recrystallization within KFZ mylonites is best described with reference to progressive fabric development. Such a transition has been studied in greatest detail in Kobbefjord proper.

The country rock at $\sim 80 \mathrm{~m}$ from the edge of the fault zone is a medium-grained quartzofeldspathic gneiss. Quartz shows some preferred orientation, undulose extinction and polygonalization along with minor recrystallization to a finer grain size. Grain boundaries are highly irregular and range from sutured to lobate. Thus, these gneisses have undergone ductile deformation during earlier episodes of flow-type folding.

As the margin of the fault zone is approached, a new fabric is first manifested by the sporadic occurrence of discrete, irregular to planar features that are marked by concentrations of mica, and very closely resemble slip or crenulation cleavage (cf. Billings, 1972, p. 391) both in hand specimen and thin section.* Recognition of these features is difficult, and individual 'cleavage' planes must be spaced no less than $0.5 \mathrm{~cm}$ apart to be noticed. This 'cleavage' is oriented subparallel to the fault zone, and displaces compositional layering in a 
sense that suggests shortening normal to the fault zone. Microscopically, this fabric is characterized by folding and breaking of biotite grains concomitant with their rotation into planar zones. Quartz has a stronger dimensional preferred orientation than in the gneissic protolith.

The boundary of the KFZ, as defined here, is marked by the first appearance of rocks with a pervasive new foliation and a much finer grain size. In Kobbefjord, the fabric transition zone alternates in an irregular way between protomylonites (i.e. fault rocks with $10-50 \%$ mylonitic matrix; cf. Sibson, 1977) and finely laminated mylonites on a 1-5 m scale over a distance of $\sim 60 \mathrm{~m}$ from east to west. The finely laminated mylonites increase in abundance until they are the only rocks present. The fault zone at this locality is distinctly assymmetric, with the most deformed rocks concentrated towards the north-west margin, whereas on Rypeø and Storø, the KFZ appears to be largely symmetric.

In laminated mylonites, quartz has assumed a strong crystallographic preferred orientation. Aggregates and single grains are greatly elongated, with aspect ratios on the order of $30: 5: 1$, and are characterized by deformation lamellae and bands, and intense wavy to undulose extinction. Recovery structures including polygonalization and subgrain formation are all common, and dynamic recrystallization to finer grain size has also occurred. Many of the new smaller grains show the same types of deformation and recovery structures as the larger grains, and tend to be concentrated in bands with granular epidote and acicular fine-grained biotite and muscovite (figure 2A, B). With further deformation, the bands of finer-grained recrystallized material occupy a progressively larger volume of rock (figure $2 \mathrm{C}, \mathrm{D})$. Although the size of the larger quartz grains/grain aggregates varies from sample to sample, and within individual samples, grain size in the finer-grained bands tends to be fairly constant $(\sim 100 \mu \mathrm{m})$ regardless of the extent of development of these bands (cf. Weathers $e t$ al., 1979). Some of this textural variation may result from multiple deformation events. The nature of grain boundaries is highly variable; in most cases they range from sutured to smooth and lobate, but several samples contain straight grain boundaries with $120^{\circ}$ triple junctions.

Very fine-grained recrystallized quartz $(10-30 \mu \mathrm{m})$ occurs in several samples of the most finely laminated mylonites which have also undergone the most intense hydrothermal alteration. These form in discrete bands that crosscut coarser grains, and are associated with planar offset of individual grains and groups of grains. This feature is not obviously controlled by the presence of a second phase, and may indicate a diffusion-controlled deformation process as suggested for similar features by White (1979).

Plagioclase in the laminated mylonites occurs typically as irregularly shaped grains $\sim 100$ $\mu \mathrm{m}$ across, with weak to moderate undulatory extinction. Larger grains (up to $500 \mu \mathrm{m}$ ) tend to be subrounded, and include strain-free porphyroblasts, and strained porphyroclasts traversed by bands of very fine recrystallized material. The distinction between 'old' and 'new' feldspar is difficult, as both types contain small, $(50-100 \mu \mathrm{m})$, elongate mica grains oriented parallel to at least two crystallographic directions. Plagioclase preserves some evidence of rotation, as indicated by curvature and alignment of albite twin lamellae parallel to the mylonitic foliation. The sense of rotation is consistent with dextral transcurrent movement. In many cases however, albite twin lamellae are 'buckled' in such a way as to suggest shortening normal to this foliation (fig. 7A), and are offset along planes subparallel to the foliation. Features of this type may be due to brittle failure, as these planes can be seen to continue into discrete microfractures in the surrounding matrix. 

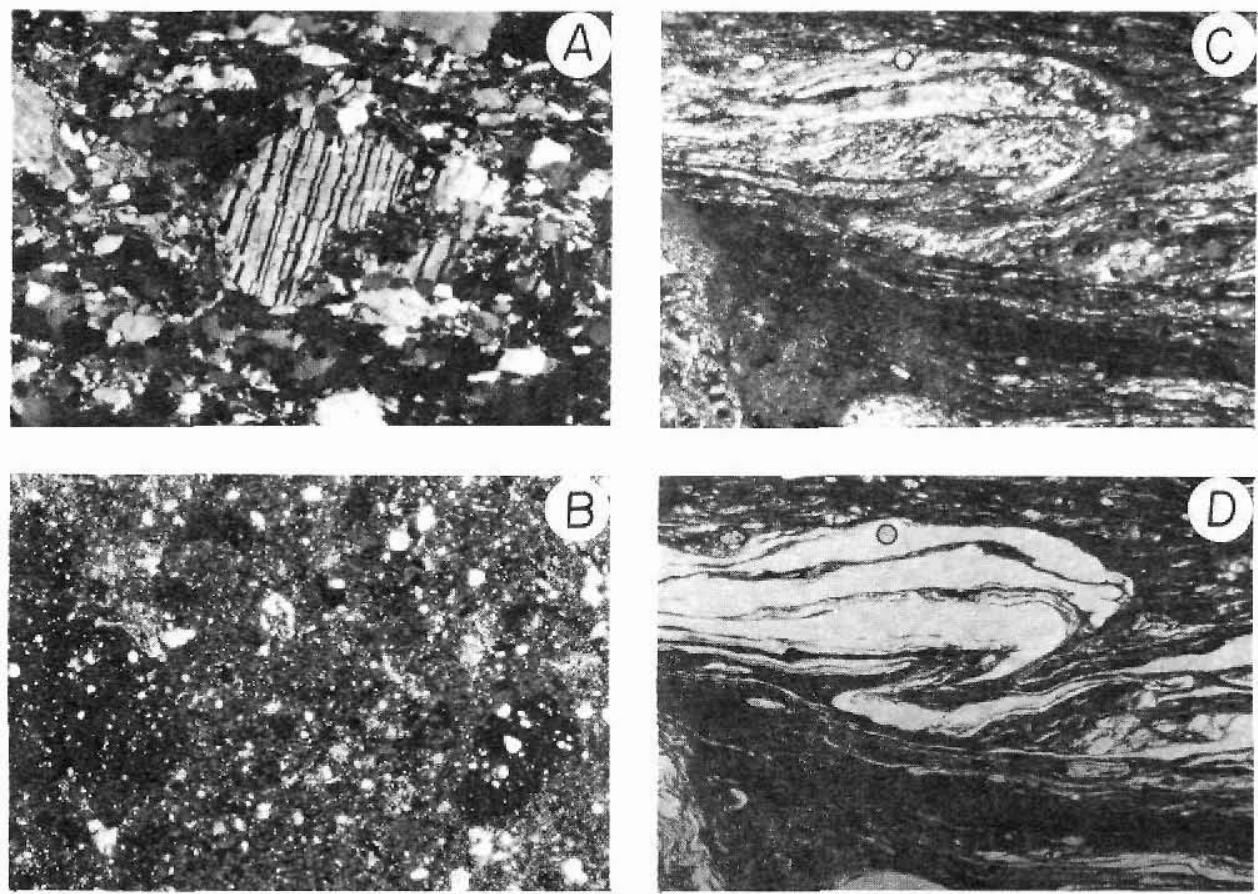

Fig. 7a. Plagioclase porphyroclast in mylonite; note 'wrinkling' and offset of albite twins (crosspolarized light; GRD-235, KFZ-Storø). b. Polyphase pseudotachylite; note abundant mineral fragments with a range in size, and dark globular clasts in somewhat paler matrix (cross-polarized light; GRD-1998, KFZ-Kobbefjord). c, d. Plane- and cross-polarized light views of isoclinal microfolding of mylonitic layers within pseudotachylite (GRD-2026, KFZ-Kobbefjord). (Horizontal dimension $=2.2$ $\mathrm{mm}$ in all photomicrographs).

\section{Brittle deformation}

Evidence for brittle deformation has been noted at all localities along the fault zone, and includes joint sets with minimal displacement, healed breccias to ultracataclasites, various type of pseudotachylites, and cohesionless gouge. Additional evidence for brittle deformation includes microfractures with a variety of orientations.

Conjugate joint sets at the margins of the fault zone are either very rare, or went unnoticed, since only three well-developed occurrences were noted. At these localities, the joint sets yield a consistent or orientation for $\sigma_{1}$, as noted previously for Amitsuarssuk (cf. fig. 6).

Rocks identified in the field as pseudotachylites are typically dark gray to green or black with a characteristic flinty appearance. In thin section, the pseudotachylites are seen to consist of subrounded to subangular, comminuted mineral particles $(<100 \mu \mathrm{m})$ dispersed throughout a dark brown partly isotropic (glassy?) matrix. This matrix ranges from massive to faintly foliated, and locally has a distinctly mottled, heterogeneous texture. The latter may be a result of polyphase history as some samples are comprised of globular pseudotachylite 'clasts' in a pseudotachylite groundmass (fig. 7B). Further evidence of this polyphase evolu- 
tion includes isoclinal microfolding of mylonitic material within a pseudotachylite matrix (fig. 7C, D).

Pseudotachylites always form in planes $(<10 \mathrm{~cm}$ wide), and commonly fill fractures oriented at an angle to these planes. Thus, pseudotachylites 'intrude' and cross-cut other fault rocks. Some of the pseudotachylites also contain rounded fragments of any local fault rock lithology, which may be as large as $5 \mathrm{~cm}$. Such 'quasiconglomerates' (cf. Sibson, 1975) form in what look like 'pull-apart' structures, and locally preserve a flow structure of aligned fragments.

At one locality in Kobbefjord, an extremely fine-grained black rock cross-cuts laminated mylonites but is also rotated and deformed parallel to the mylonitic foliation. We interpret this as a pseudotachylite which underwent subsequent ductile deformation. If this interpretation is correct, it indicates the transient operation of brittle deformation mechanisms in an otherwise ductile regime. Sibson (1977) has suggested that such features represent downward propagation of seismic fracturing.

Cataclasites are distinguished in the field from those rocks referred to above as pseudotachylites by their paler color, chalky aspect, and absence of rounded inclusions. In thin section, cataclasites are characterized by angular mineral fragments ranging in size from several millimeters to a few micrometers; thus there is no apparent matrix here but rather a continuously variable decrease in grain size. Microscopic (millimeter size) examples are developed in zones that crosscut the local foliation at low to moderate angles $\left(<45^{\circ}\right)$.

In outcrop, cataclasites also crosscut the mylonitic foliation. One 'dike' on Rypeø is $\sim 1 \mathrm{~m}$ wide and contains angular inclusions of the mylonitic host up to $0.5 \mathrm{~m}$ across. In Kobbefjord, a single 1-2 cm wide 'vein' crosscuts the mylonitic foliation and can be traced for $\sim 30 \mathrm{~m}$. Cataclasites of the type described here are probably the result of frictional sliding (cf. Sibson, 1977).

Carbonate and quartz veins are also present, but their systematic distribution and orientations have not been studied.

Most samples studied petrographically contain abundant microfractures. These crosscut the mylonitic foliation at angles ranging from $30-60^{\circ}$, but locally occur normal to this foliation. The extent of movement on any microfracture ranges up to $\sim 3 \mathrm{~mm}$, based on textural criteria such as offset single crystals.

\section{Alteration}

Extensive hydrothermal alteration is associated with most of the KFZ. The most highly altered rocks are typically the most deformed ones (i.e. mylonites with the finest grain size). However, there are extensive zones of retrogression and silicification in relatively undeformed rocks adjacent to the fault zone indicating a broad alteration halo.

Quartzofeldspathic gneisses in the KFZ are progressively altered from quartz + plagioclase + biotite \pm hornblende $\pm \mathrm{K}$-feldspar rocks to ones containing quartz + albite + epidote + muscovite \pm calcite \pm chlorite. The most extensively altered mylonites contain little chlorite, and are predominantly quartz-plagioclase-epidote rocks with minor muscovite and abundant disseminated hematite. In these rocks, quartz-rich bands have undergone extensive recrystallization, and epidote grains are subhedral and well-formed (fig. 2E, F). Where mafic dikes are deformed and altered by the fault zone, their most deformed portions 
contain chlorite + epidote + quartz + calcite \pm actinolite, whereas less deformed parts also contain green hornblende and highly altered plagioclase.

On Rypeø, there is a direct relationship between fracturing and alteration as the margin of the fault zone is approached. The first altered fractures appear $\sim 75 \mathrm{~m}$ before the first occurrence of the incipient 'cleavage' fabric described previously. The extent of alteration increases irregularly towards the fault zone and ultimately becomes complete. A similar type of alteration can be found at the other localities, but the width of the zone of completely altered rocks appears greatest at Rypeø.

The alteration in rocks adjacent to the KFZ involves sporadic, but locally pervasive, development of chlorite, muscovite, epidote and calcite. In one sample, prehnite occurs in quartz-rich veins. Gneisses also show various degrees of silicification and feldspathization.

All of these features indicate that extensive fluid flux and metasomatism were part of the faulting process, although the extent to which these occurred was highly variable. Moreover, the alteration process involved not only the formation of hydrated assemblages, but also abundant carbonate (locally), suggesting a significant $\mathrm{CO}_{2}$ input. The ultimate source of these fluids - particularly the $\mathrm{CO}_{2}$ - is problematic; it may involve convective recirculation from higher crustal levels, combined with components derived from the lower crust and/or upper mantle.

\section{Other faults in the Godthåbsfjord region}

Several other faults that are similar in many respects to the KFZ occur in the Godthåbsfjord region. This similarity includes the development of laminated mylonites, the presence of hydrothermal alteration zones, and dextral transcurrent sense of movement (where recognizable). McGregor (1973) noted a few of these faults on his map, including the location of the KFZ near Godthåb. On a subsequent expanded geological map, McGregor (1979) also noted the inferred position of the Ataneq fault. (The latter is probably as important a structural discontinuity as the KFZ, but its location and deformation characteristics are not well-constrained at the present time). Berthelsen \& Bridgwater (1960) mention two faults in Qugssuk, the northern extension of Godthåbsfjord. James (1974) and Macdonald (1974) describe the occurrence of fault zones on Bjørneøen and in Nordland.

On figure 1, we have located these faults, together with others identified by us. Although most of these are $<\sim 10 \mathrm{~m}$ wide, they can be traced for several $\mathrm{km}$. Numerous smaller faults are also present, but have not been indicated on the figure.

The important point here is the presence of a large number of faults with similar sense of movement, which we interpret to indicate that they developed in response to the same stress field (i.e. with $\sigma_{1}$ oriented WNW). The only noteworthy exception to this is a high-angle reverse fault on Bjørneøen (indicated as a thrust fault on figure 1), which may have formed to accommodate deformation between the Ataneq fault to the north and the KFZ to the south.

\section{Discussion}

\section{Deformation history inferred for the $K F Z$}

The sense of displacement of paragneiss units on Storø Malene, the orientations of foliations and lineations, the slight angle between the fault trace and foliation strike, and the 
sense of rotation for mafic dikes deformed in the fault on Storø, all indicate dextral transcurrent movement for the KFZ.

Our present knowledge of the mineral assemblages associated with fault-related alteration and retrogression is inadequate for us to constrain the $P-T$ environment beyond the simple statement that greenschist grade conditions prevailed. Moreover, although there is a clear spatial relationship between alteration and deformation, we are unsure as to the temporal relationship, and exactly how alteration and associated fluid flow may have affected mechanical properties of the fault rocks and vice-versa.

The overall picture that emerges for the KFZ is one in which brittle deformation supercedes ductile deformation. This is consistent with models proposed for a transcurrent fault zone that remains active as any one point along it moves to a shallower level with time, thus passing through successive $P$ - $T$ regimes that dictate which type of deformation mechanism is dominant (cf. Grocott, 1977).

\section{Deformation mechanism inferred for the $K F Z$}

Certain field observations, particularly those in the fabric transition zone at the boundaries of the KFZ, suggest shortening normal to the fault. It is unclear whether this is indicative of a flattening deformation or not. The elongated nature of mineral grains and aggregates, however, does suggest stretching subparallel to the fault. Further measurements on aspect ratios of deformed objects are needed to clarify these points.

Despite this uncertaintly, the nature of lineations and foliations measured along the KFZ is consistent with the model proposed by Escher \& Watterson (1974) for fabrics formed in zones dominated by ductile simple shear. These authors have shown that in such a shear zone, the $X$-direction of the strain ellipsoid is rotated towards parallelism with the shear direction, and the $X-Y$ plane rotates towards parallelism with the shear plane. Several studies have confirmed this (e.g. Grocott, 1979; Burg \& Laurent, 1979), and Sibson et al. (1979) have shown that for the Alpine Fault in New Zealand, the strike and plunge of lineations defined by ellipsoidal quartzofeldspathic aggregates correspond reasonably well to the orientation of the earthquake slip vector. With respect to the KFZ, the $X$-direction corresponds to stretching lineations, the $X-Y$ plane is represented by mylonitic foliations, and the shear plane parallels the strike of the fault.

\section{Age of faulting}

The shear zones in Amitsuarssuk cut the $\sim 2550$ Ma Qôrqut Granite Complex, which places a definite upper limit on the age of the KFZ. A better estimate for the actual timing of fault movement could be obtained from the ages of mafic dikes that are affected by the fault. Unfortunately, to the best of our knowledge, no mafic dikes in the Godthabsfjord region have yet been dated. However, the timing of fault movement can be constrained by analogy to events outside the region of Godthåbsfjord.

For example, Berthelsen (1957) describes the Fiskefjord fault system (just north of the region shown in figure 1), as a series of dextral wrench faults that displace $\mathrm{N}-\mathrm{S}$ trending mafic dikes up to $\sim 3 \mathrm{~km}$. A group of later ENE to EW trending mafic dikes parallel the Fiskefjord fault system, and are themselves locally altered by rejuvenated fault movement. Berthelsen \& Bridgwater (1960) have correlated these dikes with Kangâmiut dikes in the 
region north of Sukkertoppen, for which an age of $\sim 2000 \mathrm{Ma}$ has been obtained (Kalsbeek et al., 1978). Thus, by analogy, the faults and dikes in the Fiskefjord region precede the 1800-1600 Ma Nagssugtoquidian overthrusting (cf. Kalsbeek, 1979).

The KFZ has a similar relationship to a NE-SW trending group of mafic dikes. On Rypeø, a thick dike is emplaced parallel to the fault zone, and deformed by it; the same dike continues into Kobbefjord proper where it parallels the fault. On Storø, several mafic dikes are subparallel to the fault zone, and we have identified two that are offset in a right-lateral direction. Similarly, in Amitsuarssuk, a mafic dike $\sim 20 \mathrm{~m}$ wide was emplaced parallel to the Kobbefjord fault.

We suggest that these NE-SW trending dikes $\left(\sim 050^{\circ}\right)$ are analogous to the ones with a similar trend in the Fiskefjord region, and that the movement along the Kobbefjord fault zone is similar in age to these dikes. If these analogies are correct, then movement on the Kobbefjord fault was initiated in the interval $\sim 2000-1800 \mathrm{Ma}$.

\section{Tectonic significance}

The similarity among the trends $\left(\sim 050^{\circ}\right)$ for the $\mathrm{KFZ}$, the Fiskefjord fault system, and other faults north of Godthåbsfjord to Alangua in the Sukkertoppen region (cf. Berthelsen \& Bridgwater, 1960) suggests that these faults developed in response to the same (or a very similar) stress regime. Our observations of the KFZ indicate that the greatest principal compressive stress $\left(\sigma_{1}\right)$ was oriented $\mathrm{W}$ to $\mathrm{NW}$, with $\sigma_{2}$ subvertical. This orientation for $\sigma_{1}$ is the same as that deduced by Chadwick (1969) in the Frederikshåb region, approximately $300 \mathrm{~km}$ south of Godthåb, based on studies of the orientations of fault and dike patterns there. The timing of this deformation was approximately the same as that for the Nagssuqtoquidian and Ketilidian compressional-thermal events on the northern and southern margins of the Archaean craton (cf. Kalsbeek, 1979; Allaart, 1976). These observations, taken together, suggest that the West Greenland Archaean craton between Frederikshåb and Sukkertoppen - a distance of $\sim 500 \mathrm{~km}$, which includes the Godthåbsfjord region - underwent predominantly simple shear deformation in the interval $\sim 2000-1800 \mathrm{Ma}$.

This transcurrent faulting within the interior of the block implices a compressionally induced deformation of a continental region. As elaborated by Watterson (1978), this situation is not unlike the 'rigid indentor' tectonic model applied recently to deformation beyond the Himalayas by Molnar and Tapponnier (1977). Watterson (1978) infers that $\sigma_{1}$ for Proterozoic deformation in Greenland was oriented N to NW. However, our work indicates that $\sigma_{1}$ was oriented $W$ to NW in the area affected by the Kobbefjord (and Fiskefjord) faults. We feel that this variation is to be expected given the probability of variation in the trend of an orogenic front, and the complexities implied by the temporal and spatial correlation of deformation in Greenland with the Hudsonian Orogeny in North America (Kalsbeek et al., 1978), which should lead to locally significant variations in principal stress orientation.

Acknowledgements. This work was supported by funding from the National Science Foundation (GRANT EAR 78-23412), National Geographic Society, and Harvard University. We wish to thank the Geological Survey of Greenland for logistical support during field work in 1980 . Several thorough reviews by staff members of the Geological Survey of Greenland helped to clarify and improve an earlier version of this paper. 


\section{References}

Allaart, J. H. 1976: Ketilidian mobile belt in South Greenland. In Escher, A. and Watt, W. S. (edit.) Geology of Greenland, 120-151. Copenhagen: Geol. Surv. Greenland.

Bell, T. H. \& Etheridge, M. E. 1973: Microstructure of mylonites and their descriptive terminology. Lithos 6, 377-348.

Berthelsen, A. 1957: The structural evolution of an ultra- and polymetamorphic gneiss-complex, West Greenland. Geol. Rdsch. 46, 173-185.

Berthelsen, A. \& Bridgwater, D. 1960: On the field occurrence and petrography of some basic dykes of supposed Precambrian age. Bull. Grønlands geol. Unders. 24 (also Meddr Grønland 123) 43 pp.

Billings, M. P. 1972: Structural Geology, 3rd ed., 606 pp. Englewood Cliffs: Prentice-Hall.

Burg, J. P. \& Laurent, Ph. 1978: Strain analysis of a shear zone in a granodiorite. Tectonophysics 47, $15-42$.

Chadwick, B. 1969: Patterns of fracture and dyke intrusion near Frederikshåb, Southwest Greenland. Tectonophysics 8, 247-264.

Escher, A. \& Watterson, J. 1974: Stretching fabrics, folds and crustal shortening. Tectonophysics 22, 223-231.

Gray, D. R. \& Durney, D. W. 1979: Crenulation cleavage differentiation; implications of solution-deposition processes. J. struct. Geol. 1, 73-80.

Grocott, J. 1977: The relationship between Precambrian shear belts and modern fault systems. J. geol. Soc. London 133, 257-262.

Grocott, J. 1979: Shape fabrics and superimposed simple shear strain in a Precambrian shear belt, West Greenland. J. Geol. Soc. London 136, 471-488.

James, P. R. 1974: Field mapping of Bjørneøen and the adjacent coast of Nordlandet, Godthåbsfjord, southern West Greenland. Rapp. Grønlands geol. Unders. 65, 58-62.

Kalsbeek, F., Bridgwater, D. \& Zeck, H. P. 1978: A $1950 \pm 60 \mathrm{Ma} \mathrm{Rb-Sr} \mathrm{wholerock} \mathrm{isochron} \mathrm{age} \mathrm{from}$ two Kangâmiut dykes and the timing of the Nagssugtoquidian (Hudsonian) orogeny in West Greenland. Can. J. Earth Sci. 15, 1122-1138.

Kalsbeek, R. 1979: Rb-Sr isotope evidence on the age of the Nagssugtoquidian orogeny in West Greenland, with remarks on the use of the term 'Nagssugtoqidian'. Rapp. Grønlands geol. Unders. 89, 129-132.

Macdonald, R. 1974: Investigations on the granulites of southern Nordland, Godthåbsfjord, central West Greenland. Rapp. Grønlands geol. Unders. 65, 44-49.

McGregor, V. R. 1973: The early Precambrian gneisses of the Godthåb district, West Greenland. Phil. Trans R. Soc. London A 273, 343-358.

McGregor, V. R. 1979: Archaean grey gneisses and the origin of the continental crust: evidence from the Godthåb region, West Greenland. In Barker, F. (edit.) Trondhjemites, Dacites and Related Rocks, 169-204. Elsevier.

Molnar, P. \& Tapponnier, P. 1977: The relation of the tectonics of eastern China to the India-Eurasia collision: an application of slip-line field theory to large-scale continental tectonics. Geology 5, 212-216.

Ramsay, J. G. 1980: Shear zone geometry: a review. J. struct. Geol. 2, 83-100.

Sibson, R. H. 1975: Generation of pseudotachylyte by ancient seismic faulting. Geophys. J. R. Astr. Soc. 43, 775-794.

Sibson, R. H. 1977: Fault rocks and fault mechanisms. J. Geol. Soc. London 133, 191-213.

Sibson, R., White, S. H. \& Atkinson, B. K. 1979: Fault rock distribution and structure within the Alpine

* (p. 119) It is possible that "pressure solution" played an important role in the development of this cleavage (cf. Gray \& Durney, 1979), but our observations are not comprehensive enough to confirm this suggestion. 
Fault Zone: A preliminary account. In Walcott, R. I. \& Cresswell, M. M. (edit.) The Origin of the Southern Alps, Bull. R. Soc. N. Z. 18, 55-65.

Watterson, J. 1978: Proterozoic intraplate deformation in the light of south-east Asian neotectonics. Nature 273, 636-640.

Weathers, M., Bird, J. M., Cooper, R. F. \& Kohlstedt, . . 1979: Differential stress determined from deformation-induced microstructures of the Moine thrust zone. J. Geophys. Res. 84, 7495-7509.

White, S. 1979: Grain and subgrain size variations across a mylonite zone. Contr. Miner. Petrol. 70, 193-202.

White, S. H., Burrows, S. E., Carreras, J., Shaw, N. D. \& Humphreys, F. J. 1980: On mylonites in ductile shear zones. J. struct. Geol. 2, 175-187.

Department of Geological Sciences, Harvard University, Cambridge, Massachusetts 02138,

USA. 